\title{
GLEANINGS AMONG THE PLEURONECTIDS, AND OBSERVATIONS ON THE NAME PLEURONECTES.
}

BY THEODORE GILL.

In "A Review of the Flounders and Soles (Pleuronectidæ) of America and Europe,"* President D. S. Jordan and Mr. David K. Goss have given a much-needed and masterly summary of our knowledge respecting the forms in question. With most of their conclusions I entirely agree, but there are various minor points in which I am compelled to dissent from them. One of the most important, and indeed the most important in some respects, relates to the application of the name Pleuronectes. For over thirty years there has been almost (but not quite) universal concurrence in restricting that name to the small-mouthed species represented by the Pleuronectes platessa of Linuæus. Messrs. Jordan and Goss, however, now object to such a use of the name, and revert to its employment by Fleming and DeKay for the Turbot and its relatives. Inasmuch as an almost settled question is thus again opened, and as the confusion induced by the proposed change would be considerable and deplorable, an immediate inquiry into the propriety of that view is desirable. Of course the fact that confusion would for a time result from the adoption of Messrs. Jordan and Goss's proposition is no material objection; but if the confusion can be averted without infraction of the laws of nomenclature, and renewed stability be obtained for the long current names, a not immaterial boon will have been realized for Ichthyology. A re-examination of the data involved in the question is therefore in order.

\section{JORDAN AND GOSS'S VIEW.}

Messrs. Jordan and Goss have given their reasons for the use of the name Pleuronectes for the Turbot aud its allies in an argument which it is only just to them to reproduce. It is found in their memoir in the Annual Report of the Commissioner of Fish and Fisheries for 1886 (pp. 255,256 ; Separate, pp. 31, 32):

Our reasons for considering the Turbot as the type of the genus Pleuronectes may be briefly'stated:

In the earliest restriction of the Linnæan genus Pleuronectes, in which the latter name is retained for one of the subdivisions, the Turbot has been retained as the type. We therefore find ourselves compelled to transfer the name Pleuronectes from the small-mouthed flounders to the present group.

The genus Pleuronecies, as it appears in the tenth edition of the Systema Naturæ, is intended to contain all flat-fishes, 18 of which are characterized and named.

* The Review was issued in advance of its appearance in the Annual Report of the Commissioner of Fish and Fisheries for 1886, with double pagination-that of the Report (pp. 225-336) and that of the Separate (pp. 1-112), and 9 plates.

Proc. N. M. $88-38$ 
Omitting foreign species, the following table shows the European species included by Linnæus, and the generic names which have since his time beeu specialiy based on each of these species:

Hippoglossus . .Hippoglossus Cuvier, 1817. Cynoglossus................................. Glyptocephalus Gott sche, 1836.* Platessa .Platessa Cuvier, 1817 ; Pleuronectes Swainson, 1839; Pleuronectes Bleeker, 1862.

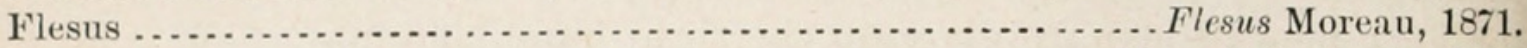

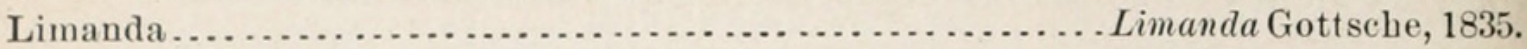
Solea ............................................... Solea Quensel, 1806. Linguatula ................ Pleuronectes Bonaparte, 1846; Citharus Bleeker, 1862; Bothus Rafinesque, 1810 ; Scophthalmus Rafinesque, 1810.

Rhombus. Rhombus Cuvier, 1817 (preoccupied).

Maximus..................... Pleuronectes Fleming, 1828; Psetta Swainson, 1839; Passer Valenciennes, 1855 (preoccupied).

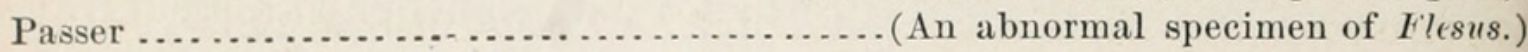

The first subdivision of the genus Pleuronectes, after the removal of the soles, seems to have been that of Cuvier. Cuvier subdivides the group into three subgenera, Hippoglossus, Rhombus, and Platessa, retaining the name Pleuronectes for the group as a whole, but for none of his subdivisions.

Fleming, next after him, makes use of these subdivisions, but rejecting the name of Rhombus, he distinctly adopts the generic name Pleuronectes for the "Turbot" group. His genera are, therefore, Pleuronectes the "Turbot," Solea the "Sole," Platessa the "Fluke," and Hippoglossus the "Halibut." Pleuronectes maximus, the "Common Turbot," is evidently intended as the type of Pleuronectes, as understord by him. This is, so far as we have ascertained, the first restriction of the name Pleuronectes to any group of flounders, and if it be so the name Pleuronectes must go with the Turbot and its relatives. In that case it would take the place of the preoccupied name Rhombus and of the prior but almost forgotten name of Bothus, unless we see fit to place the Turbot and the Brill in different genera, in which case Bothus should be used for the Brill.

The next restriction seems to be that of Swainson, in 1839, who indicates Pl. platessa as the type of Pleuronectes.

Next is the restriction made by DeKay, 1842, who again makes the Turbot the type of Pleuronectes by adopting the then nearly obsolete name of Pleuronectes in place of Rhombus. In 1846 Bonaparte retained the name Pleuronectes for a group composed of Citharus, drnoglossus, etc. The only Linnæan species mentioned by him, linguatula, may be regarded as his type.

In 1862 Bleeker, and following him Günther and nearly all modern authors, have regarded Pleuronectes platessa as the type of Pleuronectes.

The reason for this view lies apparently in the fact that Artedi before Linnæus had mentioned the species later called platessa first in his list of species of Pleuronectes. This reason is now regarded as an insufficient one, and the name Plturonectes must retain the signification given it by the first author, who has properly restricted it. We must therefore follow Fleming in regarding Pleuronectes maximus as the proper type of Pleuronectes.

This historical summary is not complete, and the results to which Messrs. Jordan and Goss have arrived are a consequence of the incompleteness of their review of the literature.

\section{LINNAAAN SPECIES.}

The species occurring in Europe and known to Linnæus have been correctly identified by Jordan and Goss, but a complete enumeration of

* This was published at the same time as Limanda, i. e., 1835. 
all the species known to the Swede may be acceptable and will show the extent of the family that his immediate successors had to deal with. As enumerated in the tenth edition of the Systema Naturæ, they are identified in the following exhibit, wherein the European species are distinguished by HEAVY TYPE, and the generic names based on them (or very near allies) are given in the right-hand column.

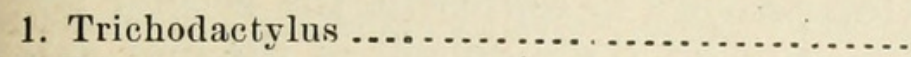

2. Plagiusa .............................................. Cuvier, 1829.

3. Ocellatus...................................................

4. Hippoglossus............................................

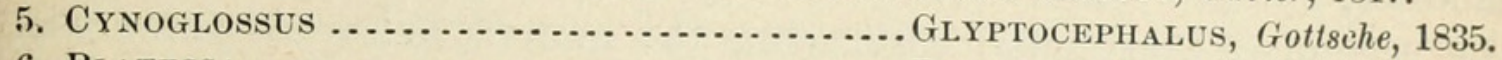

6. Platessa …............................................ 1817.

7. Flesus ............................................ Morean, 1881.

8. Limanda.................................................. Gottsche, $1-35$.

9. Solea .................................................. Quensel, 1806.

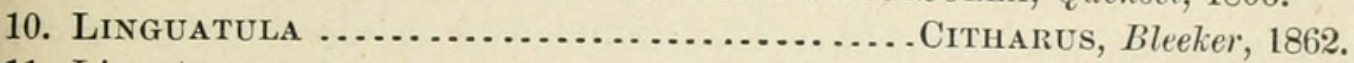

11. Lineatus ............................................. Lacépède, 1803.

12. Rномвus ......................................... Rafinesque, 1810.

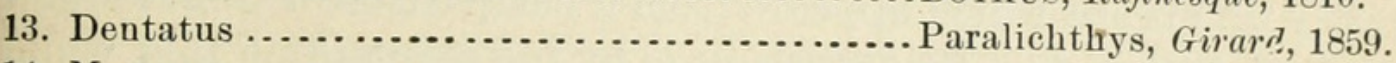

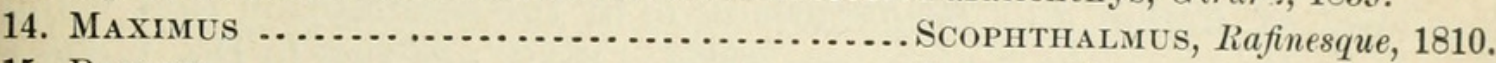

15. Passer .............................................. Moreau, 1881.

16. Papillosus............................................... Ranzani, 1840.

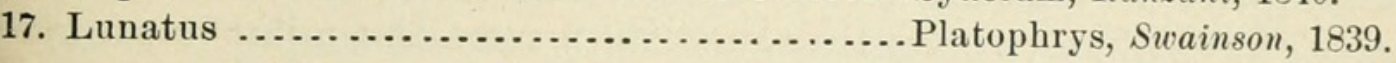

The genera of true Pleuronectidæ thus referred to were proposed in the following chronological order:

1810. Bothus, Raf. Scophthalmus, Raf.

1817. Hippoglossus, Cuv. Platessa, Cuv.

1835. Limanda, Gottsche. Glyptocephalns, Gottsche.
1839. Platophrys, Swains. Psetta, Swains.

1840. Syacium, Ranz.

1859. Paralichthys, Girard.

1862. Citharus, Bleeker.

1881. Flesus, Moreau.

\section{FIRST SUBDIVISION OF PLEURONECTES.}

"The first subdivision of the genus Pleuronectes, after the removal of the soles," does not seem "to have been that of Cuvier." Years before, Rafinesque had subdivided the genus and enumerated all the minor genera known to him.

In 1810, in his Caratteri di alcuni nuovi generi e nuove specie di Animali e Piante della Sicilia (p. 23), he proposed a new generic denomination (Bothus) for a portion of the genus Pleuronectes, but would have called it Rhombus, after the chief species, had not that name been already used for another genus.* He included in it, besides the " $B$. rhombus [Pleuronectes rhombus, Lin.]," three supposed new species, $B$. Rumolo, B. Tappa, and B. imperialis. Of the three species B. Rumolo

* Porzione delle specie dei genere Pleuronectes degli autori compongono questo nuovo mio genere, il quale si dovrebbe chiamare Rhombus della principali delle specie che contiene, se Lacépède non avesse gia attribuito tal nome ad altro suo genere. Il nome di Bothus è però, un di quelle data da Aristotle di Pesci ai quest' ordine. 
is the same as the Linnæan species, B. Tappa probably Arnoglossus laterna, and B. imperialis has been supposed to be identical with the Arnoglossus Grohmanni, and by Bonaparte identified with the Turbot,* but the proportions and rays assigned by Rafinesque preclude the latter.

In 1810, also, but somewhat later, Rafinesque, in his Indice d' Ittiologia Siciliana (pp. 13, 15), enumerates the Sicilian Heterosomes known to him. He considered the Heterosomes to represent the second section (i Pleurostomi) of the first division (i Giugulari) of the first subclass (i Pomniodi) of fishes, and distributed them into two orders or families, one (gli Aghirini), containing the new genus Symphurus, and the second (i Pleronetti) embracing the genera Solea, Scophthalmus, and Bothus. Scophthalmus was a new genus, embracing the S. maximus (Pleuronectes maximus Lin)., S. rhombus (Pl. rhombus Linn.), and S. diurus, a species based on the alia Passeris species of Rondelet (lib. II, cap. 8, fig. (=Pleuronectes platessa?). The genus was solely distinguished by the jugular fins and caudal fin free, and eyes on the left side.t

The only difference which appears from a comparison of Rafinesque's diagnoses of Bothus and Scophthalmus is in the assumption that while there is only one ventral fin in the former there are two in the latter.t This assumption is baseless, as all the species referred to the two nominal genera have alike two ventrals, although very dissimilar in propor. tions on the respective sides. The two genera are identical, and indeed the Brill, which seems to have been at first regarded as the type of the genus Bothus, and is also the same as the B. Rumolo, is, in the later work, transferred to the genus Scophthalmus. The two names should therefore be regarded as strict synonyms.

But, in any case, the European species contained in the genus Pleuro. nectes, as recognized by Messrs. Jordan and Goss, were formally with. drawn from the Linnæan genus and referred to one or other of his genera by Rafinesque.

In 1815, Rafinesque in his Analyse de la Nature (Palermo), for his system of Ichthyology, classified the Heterosomes or Pleuropsia as follows:

\section{II ${ }^{e}$. Sous, ord. Pleuropsia.}

$4^{\mathrm{e}}$ Fam. Pleuronectea.

$1^{\text {re }}$ S.-Fam. Achiria.

Achirus.

Symphurus.

Monochirus.

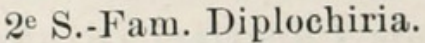

Pleuronectes.

Scophthalmus, R.

Bothus, R.

Plagiusa.

It will thus be seen that Rafinesque had not only first eliminated the Pleuronectes rhombus and P. maximus from the mass of the Linnæan

* Bonaparte, Cat. Pesci Enropei, p. 49*, s. n. Psetta maxima, syn. = "Bothus imperialis, Raf. Car. ex natur."

†"V. Gen. Scophthalmus. Ale giugulare, ed ala caudale sciolte, occhj alla sinistra." Raf., o. c., p. 53.

‡"XXIII. G. Bothus. I due occhi alla sinistra, ale dorsale ed anale distincte e Beparate della caudale, una sola ale giugulare." Raf., Caratteri, p. 23. 
genus, but also soon afterwards restricted the name Pleuronectes to a residuum left after the institution of the other genera recognized by him. Obviously, then, the generic name Pleuronectes should not have been retained afterward for any species of the genera first eliminated. The fact that Fleming, and later still DeKay, restricted the name to the Turbot and its kindred, in no way affects the question and is only evidence of their want of knowledge. Our attention will only be needed, then, to any proposals to restrict the name within the limits left by Rafinesque.*

\section{BONAPARTE'S USE OF THE NAME PLEURONECTES.}

In 1832, Charles Bonaparte, in his classification of the Vertebratest (p. 117), divided the family Pleuronectidae as follows:

\section{Famiglia 24. Pleuronectide.}

289. Pleuronectes, L.

1. Platessa, Cuv ............. Atl. eur. americano................ $\neq 10$

2. Hippoglossus, Cuv .......... Ind. Med. Atl.................... 10

290. Rhombus, Cuv. (Bothus

Rafin.) ..................... Ind. Med. Atl

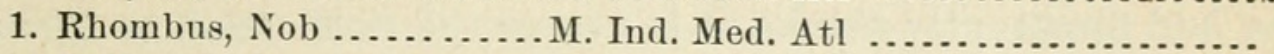

2. Bothus, Nob .............. Mediterraneo. Atl...................

291. Solea, Nob.

1. Solea, Cuv ................... Ind. Med. Atl

2. Monochir, Cuv ............. Ind. Med. Atl.................. 7

3. Achirus, Lacép .............. Am. Ind...................... 4

4. Plagusia, Brown ........... Am. Ind ..................... 6

In 1833, Bonaparte, in his Fauna Italica, $\S$ in the article on Pleuronectes macrolepidotus, proposed a new arrangement of the family Pleuronectida and gave the name Pleuronectes to a new subdivision of the old genus.

The outlines of his arrangement of the family may be given in his own words :

In sei generi merita a nostro giudizio d'esser rípartíta l'intiera famiglia, e questi diremo Platessa, Hippoglossus, Pleuronectes, Rhombus, Solea, Plagiusia; i primi quattro constituiscono i nostri Pleuronectini, i rimanenti formano la sottofamiglia dei Soleini.

The genus Pleuronectes is thus limited:

Il nostro genere Pleuronectes ha i denti mascellari e i faringei tutti acuti. La pinna dorsale ba origine al di sopra degli occhi, oppure piu innanzi; tanto essa, quanto l'anale si prolungano fino alle coda. Il corpo è ovato-oblungo quasi scolorato da ambedue i lati pellucido. Lo scaglie grandi, caduche. L'ano s'apre nelle carena del ventre.

*Rafinesque's reference of his "Scophthalmus diurus" to that genus was simply the result of a misunderstanding. His reference of Pleuronectes platessa to Solea was an example of his general blundering proclivity.

+ Saggio di una distribuzione metodica degli Animali Vertebrati di Carlo Luciano Bonaparte, Principe de Musignano. Roma. Presso Antonio Boulzaler, 1831[-1832].

$\ddagger$ The numbers in the right-hand column indicate the supposed number of species of each subgenus.

¡j Fauna Italica, Fasc. Iv, 1833. 
The species referred to this genus and illustrated by Bonaparte were P. bosci, P. macrolepidotus, P. arnoglossus, P. Grohmanni.

In 1846, Bonaparte, in his Catalogo metodico dei pesci europei (p. $\left.47^{*}\right)$, retained the genus with the same species, only substituting the name $P$. citharus for $P$. macrolepidotus (on account of doubt as to the identity of his species with Bonnaterre's) and adding the P. casurus Penn. (=Arnoglossus laterna J. \& G.) and P. megastomus Donovan (=Lepidorhombus whiffiagonis J. \& G.).

Only the Bonapartean work of 1846 is referred to by Jordan \& Goss (p. 253) in the synonymy of the genus Citharus. The type is said by them to be "linguatula, the only Linnæan species mentioned." But the name linguatula is not mentioned by Bonaparte either in his enumeration of the species of the genus or in the "Addenda" to his work. On the contrary, it appears that he was entirely uncertain as to the relationship of the Linnæan species, and appears to have had no idea that it belonged to his own genus called "Pleuronectes, Bp. (L. part)" for, under the Soleine species "Michrochirus lingula" (p. 50*), he adds "Monochirus linguatula (Rono. 324!) Cuv. Su. nec Pl. linguatula, L. Schn. (Quid?)." In other words, he wants to know what the Linnæan species is, and apparently thinks it is nearer the Soles than to Pleuronectes, as understood by him. Therefore Bonaparte's genus Pleuronectes, not containing a single one of the Linnæan species by name at least, can not be retained.

\section{RESTRICTION OF PLEURONECTES TO P. PLATESSA.}

In 1839, William Swainson in his work on the Natural History and Classification of Fishes, Amphibians, and Reptiles (Vol. II, 1839, pp. 187, 302), formally restricted the genus Pleuronectes to the P. platessa group, that species indeed being the only one mentioned by him. This use of the name was subsequently adopted by Gill (in 1861), Bleeker, Günther, and recent naturalists generally. In 1861, indeed, I had examined into the question and consulted all the authorities now mentioned with the same results as now indicated, and had used the "Genus Pleuronectes (Artedi) (non Bonap.)".*

That use of the name, I think, should be persisted in, and I doubt not that Messrs. Jordan and Goss will revert to the same opinion, or perhaps restrict it to a genus typified by P. flesus.

\section{PROPER NAMES OF THE GENERA CALLED PLEURONECTES.}

The genus to which the name Pleuronectes should be restricted, as already proved, is that one typified by the $P$. platessa, the one for which it has actually been employed for nearly three decades.

The genus to which the name was given by Bonaparte was subsequentiy divided, and to one the name Citharus was given by Bleeker in 1862, and the other was called Arnoglossus at the same time.

\footnotetext{
* Catalogue of the Fishes of the Eastern Coast of North America, p. 50.
} 
Although Citharus has been used withont challenge since its proposal in 1862 , there are objections to its use in such connection which have been universally overlooked.

In 1838, the elder Reinhardt, in his ichthyological contribution to the Greenland Fauna,* formally used the name "Citharus" for a genus of Pleuronectids consisting of $\mathrm{Pl}$. platessoides and $\mathrm{Pl}$. limandoides, calling the former "Citharus platessoides, Fab." $\dagger$ Those fishes, he thought, ought to form a peculiar subgenus, if we would follow the principles of Cuvier, and the place of that subgenus wonld be between Platessa and Hippoglossus. It was distinguished by the uniserial teeth, which are acutely pointed, distant, and largest in front of the jaws, by the large mouth, and by the development of eight branchiostegal rays. This subgenus Reinhardt called Citharus, he thus availing himself of a name employed by Rondelet, but without knowing what the Mediterranean species so named was. Cuvier, he remarked, considered it to be the Pleuronectes limandoides which occurs in the North Sea, but (Reinhardt expressly adds) individuals from the two localities had not yet, it would seem, been directly compared.‡

The name Citharus, in fact, was used by Reiphardt for the species of Hippoglossoides, and for them alone, and the characteristics assigned to the genus as well as his remarks expressly exclude the true Citharus of the Mediterranean Sea. Inasmuch, then, as the Mediterranean species referred to the genus Pleuronectes by Bonaparte, and later as the type of the new genus Citharus by Bleeker, remains without a name, Eucitha-

* Ichthyologiske Bidrag til den Grönlandske Fauna, af Johannes Reinhardt. $<\mathrm{K}$. Danske Vidensk. Selskabs Nat. og Math. Afhandl., v. 7, 1838, p. 130.

†Op. cit., p. 116.

$\ddagger$ As the memoir of Reinhardt is inaccessible to many investigators, his remarks on Citharus are here reproduced:

Nr. 47. Det synes som, at Pleuronectes platessoides tilligemed Pleuronectes limandoides Bloch bör, naar man vil fölge de samme Grundsætninger, som have bestemt Cuvier til at danne de i hans Règne animal opstillede Underslægter, ogsaa danne en egen Underslægt, hvis Plads vil være imellem Platessa og Hippoglossus ; denne Underslægt har ligesom Platessa Tænderne i Kjæverne stillede i en eneste Rad, men adskilles fra denue ved det större Gab og de meget spidse, længere fra hinanden staaende og i Kjævernes forreste Deel længere Tænder, som i begge Mellemkjævebenene sidde med regelmæssigt aftagende Længde ligened til Mundvinkelenden af disse; imedens hos Platessa Tænderne ere stumpe; omtrent af lige Længde, i Overkjævebenets höire Arm (paa Öiesiden af Hovedet) staae enten ingen, eller fra 2 til 4 Tænder. Denne nye Underslægt vil have det store Gab og spidse Tænder tilfælleds med Hippoglossus ; men hos denne er̃e Tænderne fortil i Kjæverne stillede i flere uregelmæssige Rader og ere afvexlende i Störrelse, imedens de ere stillede i en Rad med regelmæssigt aftagende Længde hos den nye Slægt, som ved otte Straaler i Gjællehuden adskiller sig baade fra Platessa og fra Hippoglossus, hvilke, ligesom de övrige af mig undersögte Underslegters Arter kun have syv Straaler. Vi kunde kalde denne Underslægt Citharus efter en af Rondelet navngivet Citharus asper fra Middelhavet, som Cuvier anseer for at være Pleuronectes limandordes Bl., der findes i Nordsöen; men Individuer fra begge Localiteter synes endnu ikke at være umiddelbart sammenlignede. 
rus may be hereafter used. The change necessary is thus reduced as much as the circumstances of the case admit.

Artedi, in 1738, had, it is true, referred to the Citharus of the ancients under the quasi-generic caption Citharus, and at one time I had assumed that the name might therefore be employed as the generic designation of the type; but not only is Artedi excluded as a non-binomial author, but it is evident that he did not really use the name as a generic desig. nation, but simply quoted it as that of the species so called in ancient times, because he could not refer it to any precise place in his system.

\section{THE GROUPS BOTHUS, PSETTA, AND LOPHOPSETTA.}

Messrs. Jordan and Goss have united the Turbot, the Brill, and their A merican representative in a single genus, but recognize a subgenus (Pleuronectes) for the first, and another (Bothus) for the last two, although the senior author had at one time considered the "subgenera" as "genera." They have overlooked some important characters, however, in the structure of the anterior dorsal rays, the extension of the lateral line on the head, and the form of the supramaxillaries, which might have led them to a different conclusion if they had been cognizant of them. The three types are certainly closely related, and their relative degrees of affinity have been well appreciated by Messrs. Jordan and Goss. There may still be a difference of opinion whether they should be regarded as representatives of one genus or of two genera or of three genera. If, however, we apply the same criterion in ich thyology as is almost universally done in ornithology, at least among the passerine birds, the three types would properly be raised to generic rank; if even we adopt all the genera recognized by Messrs. Jordan and Goss, consistency would be best manifested in such recognition. Their superficial similarity, even, is less than that between Citharichthys and Etropus Jordan and Gilbert, as may be inferred from the fact that Messrs. Jordan and Goss failed at first to recognize any difference between two species which they subsequently referred to different genera.*

\section{NEW GENERA.}

The species which were associated by Bonaparte with the $P$. macrolepidotus (Eucitharus linguatula), and which were afterwards segregated by Bleeker and later writers in the genus Arnoglossus, may still retain that name. But two of the species referred by Jordan and Goss with doubt to that genus do not belong to it; these are the $A$. (?) fimbriatus and the $A$. (?) ventralis, known to the authors in question only from the original descriptions. These I have been enabled to study and compare with their relatives. The A. (?) fimbriatus was first described by Messrs. Goode and Bean under the name Hemirhombus fimbriatus, and

* Citharichthys microstomus was for a time referred to the genus Etropus and Etropu rimosus considered as identical with it. See Jordan and Goss's Review, pp. 54 (278) vs. 108 (332). 
occurs in deep waters of the Gulf of Mexico. It was thought by Jordan and Goss to be "probably type of a distinct genus." * It actually is the representative of a hitherto undefined genus which may be named and diagnosed as follows:

\section{CYCLOPSETTA.}

Psettines with the body oblong rhombo-ovate, covered with reguiarly imbricated moderate cycloid scales; lateral line nearly rectilinear on both sides; snout convex; mouth very large; jaws squarely truncated behind; teeth uniserial, those of upper jaws moderate, of lower jaw enlarged and largest at sides; dorsal and anal almost symmetrical, $\dagger$ dorsal commencing in front of eye on snout, scarcely deflected on blind side; caudal slightly pedunculate and convex; pectorals subequal and with a subtruncate free margin; ventrals nearly equal, the left on the preanal ridge, the right lateral, both with the inner rays connected by membrane to the body; interbranchial membrane imperforate; gill-rakers tubercular and surmounted by blunt denticles.

Type C. fimbriata.

The scales on the eyed side are regularly cycloid with the nucleus some distance from the posterior margin and with numerous radiating strix. The gill-rakers are quite characteristic.

The $A$. (?) vontralis was originally made known by Goode and Bean as the Citharichthys ventralis, and likewise lives in the deep parts of the Gulf of Mexico. It was considered by Jordan and Goss to be "perhaps type of a distinct genus." It is such and may receive the name of

TRICHOPSE'TTA.

Psettines with the body oblong, rhombo-oral, covered with adherent ctenoid scales; lateral line with an arch differentiated in front on eyed side, obscure but rectilinear on blind side; profile incurved or rectilinear; mouth large; supramaxillary bones obliquely truncated behind; teeth small, somewhat enlarged and hooked in front, uniserial; dorsal and anal symmetrical behind, dorsal commencing on snout and deflected towards right nostril; caudal subsessile and convex; pectorals very unequal, the left obtuse, the right with the second and third rays extended and filiform; ventrals both free, very unequal; the left fin on the abdominal ridge with a moderately broad base and six rays, the last of which is attached by membrane to the ridge; the right fin with a narrower base (and in the males with the inner four rays setiform, but in the female nearly similar to the left fin); interbranchial membrane imperforate; gill-rakers slender and unarmed.

* Jordan and Goss, op. cit., p. 332.

+ Symmetrical in this connection refers to the fact that the fin is not decurved on one of the sides. 


\section{Type T. ventralis.}

The greatest height is about the end of the first third of the length, and thence the decurvature is regular toward the eye; the scales are mostly rounded or even subtruncate and rarely angulated behind, and their marginal teeth very stout on the eyed side, but on the blind side they are regularly cycloid. The faintness of the lateral line on the blind side, the posterior truncation of the supramaxillaries, and the development of the pectorals and ventrals, especially in the males, differentiate the genus from Arnoglossus.

\section{COMPARATIVE RELATIONS.}

The genera just described fall into the places below indicated in Messrs. Jordan and Goss's synoptical scheme of the genera of Psettince. The following table is essentially reproduced from the memoir, the chief deviation being in the value given to the absence or presence of the pectoral fin of the blind side and the character of the teeth, whether well separated or crowded into villiform bands. The deviations are indicated by the italicized portions. The table is partially artificial and confirmation or proper allocation of the several groups awaits a comparative study of their anatomy. Monolene, not examined by Jordan and Goss, and considered by them to be "of uncertain relationship," is related to the genera to which it is approximated, as I have ascertained by a study of the types of both the species.

\section{ANALYTICAL TABLE OF PSETTINA.}

$a$. Septum of gill cavity between gill arches and the termination of the shouldergirdle with a large foramen; the emargination below the shoulder-girdle near the isthmus not deep; lateral line with a strong arch in front; last rays of dorsal and anal inserted more or less on the right side of the median line; teeth subequal, in bands.

$b$. Vomer toothless; ventral fins free from the anal; caudal fin subsessile; scales small, each with very long spinules; vertebræ (regins) $10+25=35 \ldots . . .$. . PHRYNORHOMBUs.

$b b$. Vomer with teeth.

c. Ventral of eyed side united to the anal; scales small, very rough ; body ovate; vertebræ (punctatus) $12+25=37$.

ZEUGOPTERUS.

cc. Ventral fins free from the anal; scales ciliated, deciduous; body oblong, much compressed; vertebræ (whiff-iagonis) $11+30=$ 41 ...................... LePIDORHombus.

aa. Septum of gill cavity below gill arches, without foramen; a deep emargination nearer the isthums; veutral fins free from anal.

d. Pectoral fin of both sides present; dorsal rays less than 100 .

$e$. Vomer with teeth; lateral line with a strong arch in front.

$f$. Body elongate; scales weakly ciliated; month very large; teeth unequal, those of the upper jaw biserial, some of them canine-like............. Eucitharus. 
ff. Body broadly ovate; scales small, cycloid, or wanting; teeth subequal, in several rows; vertebræ 31 to 36.

g. Scales obsolete or reduced in number, replaced in part by scattered bony tubercles on eyed side; dorsal with the anterior rays unbranched and well connected by membrane; vertebre about $31 . . . . . . . . . . . . . . .$. . PsETTA.

gg. Scales well developed and regularly imbricate; dorsal with the anterior rays more or less branched, and imperfectly connected by membrane; vertebra about 36.

gg1. Lateral line developed behind lower eye; dorsal with about seven branched rays; supramaxillary squarely truncate behind and not produced at its lower angle; gillraker's about $4+12 \ldots . . . . . . . . . .$. Bothus.

$g g^{2}$. Lateral line not developed behind lower eye; dorsal with eleven to thirteen branched rays; supramaxillary obliquely truncate behind, and produced at its lower angle; gill-raktrs about $8+2 \cdot 2$......... LOPHOPSETTA.

$e e$. Vomer toothless; ventral fins free from anal; caudal fin subsessile.

$e e^{1}$. Teeth distant and in one or two rows.

$h$. Lateral line with a distinct arch in îront; teeth small, uniserial, or imperfectly biserial.

$i$. Interorbital area a narrow ridge, sometimes with a median groove.

$j$. Scales weakly ciliated or cycloid, deciduous; vertebra $10+28=$ 38 ; supramaxillaries with a posterior process from the lower angle................ AnNogLossus.

jj. Scales strongly ctenoid, adherent; supramaxillaries obliquely truncated behind ............... TRICHOPSETTA.

ii. Interorbital space more or less broad, deeply concave; scales small, ctenoid, adherent; body ovats (pectoral of left side usually filamentous in the male); vertebr:e (lunatus) $9+30=39 \ldots$. PLATOPHRYs.

hh. Lateral line without arch in front; scales ciliated.

$k$. Teeth in upper jaw biserial, in the lower uniserial, the front teeth of the upper jaw enlarged; vertebræ

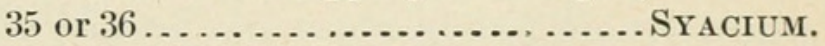

$k k$. Teeth in both jaws uniserial; interorbital space very narrow, the ridges coalescing between the eyes.

l. Mouth not very small, the maxillary more than onethird length of head.

$m$. Gill-rakers very short and thick, tubercle-like; scales small, firm ctenoid ................. Azevia.

mm. Gill-rakers slender, of moderate length; scales thin, deciduous, ciliated; vertebræ 34 to 40.

$\mathrm{mm}^{1}$. Head much compressed, with the interorbital region flat and level with the eye..... CithHARICHTHYs. $\mathrm{mm}^{2}$. Head moderately compressed, with the interorbital region sloping outwards and projecting over the lower eye ................... ORTHOPSETta.

1l. Mouth very small, the maxillary less than one-third length of head .................. Etropus.

hh. Lateral line without arch in front; scales cycloid.

kkk. Teeth in both jaws uniserial, of lower enlarged and largest on sides ....................... CYCLOPSETTA.

$e e^{2}$. Teeth crowded in villiform bands. THYSONOPSETTA。 
$d d$. Pectoral fin of blind side wanting; eyes very close together; caudal fin sub. sessile; teeth small, uniserial; mouth moderate; lateral line of eyed side arched, that of right side less so or nearly straight; dorsal fin beginning on snout, its anterior rays not exserted, its rays all simple and very numerous; scales small; body thin, very elongate; vertebræ (sessili-cauda) 43; (deep-sea flounders).

MONOLENE.

SYNAPTURA, NOT BRACHIRUS.

I embrace this opportunity also to forestall the retention of the name Brachirus instead of Synaptura. Messrs. Jordan and Goss have adopted the former and given their reasons for so doing in the following words:*

We retain the name Brachirus (i. e., Brachychirus), notwithstanding the priority of the name Brachyrus, which seems to have the same meaning. If, however, this name of Swainson be rejected, that next in order of date is Synaptura, which has now the advantage of general usage.

But fortunately we are relieved from adopting that malformed name for the reason that Swainson had, on a previous page of the same work (v. 2, p. 71), applied exactly that form to the genus on a subsequent page (p. 264) designated Brachyrus. On the former page Swainson, comparing the subgenera of Macrochirus (p. 71) or Pterois (p. 264), remarks that "in Brachirus the pectorals are again shortened, and the rays connected and branched." Thus the name is first attached to the group so characterized, and can not be applied afterwards to another genus. Synaptura must therefore be retained, which is fortunate, as it truly "has now the advantage of general usage."

COINCIDENCE OF INCREASE OF VERTEBR A AND INCREASE OF LATITUDE.

Messrs. Jordan and Goss direct attention to a certain coincidence between conditions of temperature and dextrality or sinistrality of the species in the following terms:

As the tropical Hippoglossina and all the Pleuronectina are sinistral species, the eyes and color being on the left side of the body, it follows that the tropical flonn. ders are nearly all left-sided species, while those of aretic and antaretic waters are chiefly dextral species, the eyes and color on the right.

They then advert to the number of vertebræ in relation to conditions of temperature. They say:

Still more curious is the relation between the number of vertebræ and the geograph. ical distribution of the various species.

It has already been noticed by Dr. Giinther and others that in some groups 0 : fishes northern representatives have the number of vertebræ increased. In no grour is this more strikiug than in the flounders, as the following table, showing the num. bers of the vertebræ in various species, will clearly show.

* Jordan and Goss, op. cit., p. 320. 
Dr. Günther formulated no such generalization. What he really did was to show that the species of Labrids (and those only) living in the temperate seas had more numerous vertebræ than those occurring in the tropical waters. His words are these, referring only to the Labridce:

In those genera which are composed entirely or for the greater part of tropical species, the vertebral column is composed of twenty-four, or nearly twenty-four, vertebræ, whilst those which are chiefly confined to the temperate seas of the northern and southern hemisphere have that number increased in the abdominal and caudal portions. ${ }^{*}$

There is no evidence that Dr. Guinther had appreciated any further correlation in fishes generally. The context shows plainly that he did not mean to extend his generalization beyond the Labrids.

The first indication that there was a correlation among fishes generally between an increase in the number of vertebræ and increase of latitude or decrease of temperature, was published by myself in $1863, \dagger$ the year after the publication of Dr. Günther's volume, in the following terms :

Dr. Günther has enunciated for the. first time a most important generalization for the Labroids which may also be extended to other families. * $^{*} *$ * This generalization is applicable to the representatives of Acanthopterygian families generally, and can be considered in connection with the predominance of true Malacopterygiau 0 fishes in northern waters, fishes in which the increase in the number of vertebræ is a normal feature.

Later, $\| \mathrm{I}$ also remarked that " the increase in the number of vertebræ in the species of Stbastes, a genus peculiar to the northern seas, affords an excellent example of the truth of the generalization elaiming an increased number of vertebræ for the cold-water representatives of Acanthopterygians." The case of the Sebastines became still more striking when Messrs. Jordan and Gilbert discovered that the number of the vertebræ in the species of Sebastichthys and Sebastodes, genera intermediate between the northern Sebastes and the tropical and subtropical representatives of the family of Scorpænids, was also intermediate.

But while claiming the generalization that there is a correlation between the increase of vertebræ and increase of latitude among fishes generally, I would not assign to it an undue value or claim for it the dignity of a law. It is simply the expression of a fact which has no cause for its being now known, if it shall ever be known. It may also be added that the generalization is true only in a general sense.

* Catalogue of the Fishes in the British Museum, v. 4, p. 65, note on Labridæ.

t Notes on the Labroids of the Western Coast of North America, by Theodore Gill. <Proc. Acad. Nat. Sci. Phil., 1863, p. 221.

$\ddagger$ The part omitted is the paragraph already quoted from Dr. Günther's work.

§It will be evident that the term "Malacopterygian" was used in the Cuvierian sense and applied especially to the Pleuronectids and Gadids as well as the restricted Malacopterygians of later writers.

\| Proc. Acad. Nat. Sci. Phila., 1864, p. 147. 


\section{SUBDIVISIONS.}

Messrs. Jordan and Goss consider all the flat-fishes to belong to one family (Pleuronectidæ) which is divided into six subfamiles :-(1) Hippoglossinæ, (2) Pleuronectinæ [=Psettinæ], (3) Platessinæ [=Pleuronectinæ], (4) Oncopterinæ, (5) Soleinæ, and (6) Cynoglossinæ. Previously Professor Jordan had, for a time at least, adopted the families Pleuronectidæ and Soleidæ. Whether these should be reunited or still kept distinct may be regarded as an open question till an anatomical investigation has been made. The views of different authors may be learned from the following partial synonym of the two groups.

\section{PLEURONECTID A.}

\section{Synonyms as family names.}

$\times$ i Pleronetti, Rafinesqu, Indice d'Ittiolog. Siciliana, p. 14, 1810.

$<$ Pleuronectia, Rafinesque, Analyse de la Nature, p. - 1815.

< Poissons plats, Cuvier, Règne Animal, [1e éd.], t. 2, p. 218, 1817 ; 2e éd., t. 2, p. 237, 1829.

< Pleuronectides, Risso, Hist. Nat. Europe mérid., t. 3, p. 245, 1826.

$<$ Pleuronectidæ, Bonaparte, Giorn. Accad. di Scienze, v. 52 (Saggio Distrib. Metod. Animali Vertebr. a Sangue Freddo, p. 38), 1832.

$<$ Pleuronectidæ, Bonaparte, Nuovi Annali delle Sci. Nat., t. 2, p. 131, 1838; t.4, p. 189, 1840.

$<$ Pleuronectidæ, Swainson, Nat. Hist. and Class. Fishes, etc., v. 2, pp. 187, 302, 1839.

$=$ Pleuronectidæ, Bonaparte, Cat. Metod. Pesci Europei, p. 47* 1846 .

$<$ Pleuronectidæ, Girard, Expl. and Surv, for R. R. Route to Pacific Oc., v. 10, Fishes, p. $145,1858$.

$=$ Pleuronecteoidei, Bleeker, Enum. Sp. Piscium Archipel. Indico, p. xv, 1859.

$<$ Pleuronectidæ, Günther, Cat. Fishes Brit. Mus., v. 4, p. 399, 186\%.

$=$ Pleuronectidæ, Gill, Proc. Acad. Nat. Sci. Phila., [v. 16], p. 215, 1864.

$<$ Pleuronectidæ, Cope, Proc. Am. Assoc. Adv. Sci., v. 20, p. 340, 1872.

$=$ Pleuronectidæ, Gill, Arrangement Fam. Fishes, p. 2, 1872.

$<$ Platessæ, Fitzinger, Sitzungsber. k. Akad. der Wissensch. (Wien), B.67, 1. Abth., p $42,1873$.

$<$ Pleuronectidæ, Jordan and Gilbert, Syn. Fishes N. Am., p. 813, 1882.

$=$ Pleuronectidæ, Jordan, Man. Vertebrates North. U. S., p. 208, 1884.

$<$ Pleuronectidæ, Jordan and Goss, Ann. Rep. Com. Fish., etc., for 1886, p. 225, 1889.

\section{SOLEID A.}

Synonyms as family names.

$>$ gli Aghirini, Rafinesque, Indice d'Ittiol. Sicil., p. 13, 1810.

$>$ Poissons plats, Cuvier, Règne Animal, [1e éd.],t.2, p. 218,1817; 2e éd., t.2, p. 237 1829.

$=$ Soleidæ, Bonaparte, Cat. Metod. Pesci Europei, p. 50*, 1846.

$>$ Soleoidei, Bleeker, Enum. Sp. Piscium Archipel. Indico, p. xv, 1859.

$>$ Plagusioidei, Bleeker, Enum. Sp. Piscium Archipel. Indico, p. xv, 1859.

$=$ Soleidæ, Gill, Proc. Acad. Nat. Sci. Phila., [v. 16], p. 215, 1864.

$=$ Soleidæ, Gill, Arrangement Fam. Fishes, p. 2, 1872.

= Soleidæ, Jordan, Man. Vertebrates North. U. S., p. 208, 1884.

Pleuronectidæ, auct. $p l$. 


\section{$2 \mathrm{BHL}$ Biodiversity Heritage Library}

Gill, Theodore. 1889. "Gleanings among the pleuronectids, and observations on the name Pleuronectes." Proceedings of the United States National Museum 11(757), 593-606. https://doi.org/10.5479/si.00963801.11-757.593.

View This Item Online: https://www.biodiversitylibrary.org/item/32566

DOI: https://doi.org/10.5479/si.00963801.11-757.593

Permalink: https://www.biodiversitylibrary.org/partpdf/40693

\section{Holding Institution}

Smithsonian Libraries

\section{Sponsored by}

Smithsonian

\section{Copyright \& Reuse}

Copyright Status: NOT_IN_COPYRIGHT

This document was created from content at the Biodiversity Heritage Library, the world's largest open access digital library for biodiversity literature and archives. Visit BHL at https://www.biodiversitylibrary.org. 